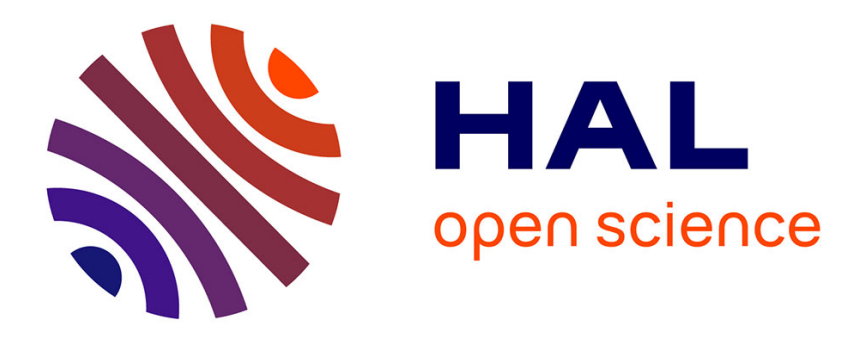

\title{
Persisting bark beetle outbreak indicates the unsustainability of secondary Norway spruce forests: case study from Central Europe
}

\author{
Tomáš Hlásny, Marek Turčáni
}

\section{- To cite this version:}

Tomáš Hlásny, Marek Turčáni. Persisting bark beetle outbreak indicates the unsustainability of secondary Norway spruce forests: case study from Central Europe. Annals of Forest Science, 2013, 70 (5), pp.481-491. 10.1007/s13595-013-0279-7 . hal-01201492

\section{HAL Id: hal-01201492 \\ https://hal.science/hal-01201492}

Submitted on 17 Sep 2015

HAL is a multi-disciplinary open access archive for the deposit and dissemination of scientific research documents, whether they are published or not. The documents may come from teaching and research institutions in France or abroad, or from public or private research centers.
L'archive ouverte pluridisciplinaire HAL, est destinée au dépôt et à la diffusion de documents scientifiques de niveau recherche, publiés ou non, émanant des établissements d'enseignement et de recherche français ou étrangers, des laboratoires publics ou privés. 


\title{
Persisting bark beetle outbreak indicates the unsustainability of secondary Norway spruce forests: case study from Central Europe
}

\author{
Tomáš Hlásny • Marek Turčáni
}

Received: 26 November 2012 / Accepted: 24 February 2013 /Published online: 5 April 2013

(C) INRA and Springer-Verlag France 2013

\begin{abstract}
- Context Secondary Norway spruce forests in the Western Beskids are among the most damaged forests in Europe. Although spruce bark beetle (Ips typographus) has been recently causing large-scale damage to these forests, our understanding of I. typographus dynamics in this environment is inadequate for evaluating forest sustainability.

- Aim This study aims to evaluate the patterns of damage caused by I. typographus to spruce forests with compromised ecological stability.

- Methods Forest infestation by I. typographus was inferred from sanitary felling data collected from 1998 to 2004. Stand and site data were obtained from forest management plans. Spatial-dependence analysis, ordinary kriging and neural network-based regression modelling were used to investigate the patterns of infestation and the casual relationships in the studied ecosystem.

- Results I. typographus long-distance dispersal substantially decreased with outbreak culmination. The spread of infestation was only weakly related to stand and site parameters.
\end{abstract}

Handling Editor: Francois Lieutier

Contribution of the co-authors Tomáš Hlásny: writing the paper, preparing the data and running the data analysis.

Marek Turčáni: co-writing Introduction and Discussion, interpreting results and coordinating the research project

\section{T. Hlásny}

Department of Forest and Landscape Ecology,

National Forest Centre, Forest Research Institute,

T. G. Masaryka 22,

Zvolen 969 92, Slovak Republic

T. Hlásny $(\varangle) \cdot$ M. Turčáni

Department of Forest Protection and Entomology,

Faculty of Forestry and Wood Sciences,

Czech University of Life Sciences, Kamýcká 1176,

Prague 6, Suchdol 165 21, Czech Republic

e-mail: hlasny@nlcsk.org
Infestations spread isotropically at the stand and patch level but directionally at the regional scale.

- Conclusions The large-scale spread of infestation can be explained by the uniform age and species composition of the investigated forests and by the ability of populations to overwhelm suboptimal trees. The observations presented here suggest that secondary spruce forests in Europe may be unsustainable due to unprecedented bark beetle outbreaks, which can be further amplified by changing climate.

Keywords Ips typographus dispersal · Declining spruce forests · Forest management - Geostatistics $\cdot$ Regression modelling

\section{Introduction}

The spruce bark beetle, Ips typographus (L., 1758) (Curculionidae: Scolytinae), is widely distributed in the Northern Hemisphere and is the most important insect pest in Norway spruce (Picea abies [L.] Karst.) forests (Christiansen and Bakke 1988; Kausrud et al. 2011; Schelhaas et al. 2003). Small I. typographus populations usually attack only stressed or damaged trees, while large populations are able to attack healthy trees and may act as primary mortality agents (Mulock and Christiansen 1986; Schroeder and Lindelöw 2002). Stress resulting from mechanical damage, drought, disrupted nutrition, or air pollution is thought to increase tree susceptibility to bark beetles, and large-scale outbreaks can develop (Dutilleul et al. 2000; Økland and Berryman 2004). I. typographus population dynamics are metastable, but diverse forests with good site-matching tend to be less susceptible to large-scale infestations than uniform forests growing in suboptimal conditions (Jactel and Brockerhoff 2007; Kausrud et al. 2011).

In recent decades, extensive degradation of spruce forests (Picea spp.) has occurred worldwide (e.g. Führer 1990; 
Uniyal and Uniyal 2009). In Europe, spruce decline has been reported from Germany (Siefermann-Harms et al. 2004), Austria (Tomiczek 1995), Poland (Grodzki 2010), Czech Republic and Slovakia (Hlásny and Sitková 2010). These forests are prone to an array of diseases and pest organisms and may be particularly vulnerable to warmer and drier climate (Seidl et al. 2008).

The role of dispersal in the spatio-temporal dynamics of $I$. typographus is generally not well quantified (Kausrud et al. 2011), and it shows differences depending on environment and population size (Botterweg 1982; Klopcic et al. 2009). In this paper, we analyse the spatio-temporal development of damage caused by the spruce bark beetle I. typographus to declining spruce forests in the Western Beskids Mts. (Central Europe), which have been subjected in the past to significant commercial overuse (Hlásny and Sitková 2010). The relatively uniform age structure and composition of such forests provide a conducive environment for I. typographus dispersal, which has not yet been studied in depth. We hypothesise that uniform structure and poor site matching of investigated forests may allow for rapid development of large-scale $I$. typographus-induced damage (Jönsson et al. 2007; Netherer and Nopp-Mayr 2005) even in the absence of windstorms, which are the main triggers of I. typographus outbreaks (Økland and Berryman 2004). We assume that the effect of stand and site characteristics on the infestation decreases with outbreak culmination (Raffa et al. 2008) and that infestation in low-diversity forests spreads more or less isotropically from the initial outbreak areas.

The purposes of this study are (1) to evaluate the patterns of forest damage caused by I. typographus to spruce forests with compromised ecological stability, (2) to investigate the relations between patterns of I. typographus dispersal and outbreak development (3) and to investigate how the infestation is controlled by stand and site characteristics. Finally, the consequences of the presented findings for forest management and for the future of secondary spruce forests in Europe are discussed.

\section{Materials and methods}

\subsection{Study region}

The research was conducted in the mountainous region at the Slovak-Polish-Czech border in the Western Beskids (Central Europe; the centre of the region is at $49^{\circ} 18^{\prime} 10^{\prime \prime}$ latitude and $18^{\circ} 47^{\prime} 07^{\prime \prime}$ longitude). The study region occupies $1,434 \mathrm{~km}^{2}$ and has an elevation ranging from 300 to 1,100 ma.s.l. Even-aged spruce forests growing outside the range of spruce natural distribution dominate the region; this forest has been constituted during the last 400 years in response to a growing need for fuel wood and construction material and has replaced the original beech-fir forests (Hlásny and Sitková, 2010). After Norway spruce (P. abies L. Karst), the main forest tree species are European beech (Fagus sylvatica L.), Scots pine (Pinus sylvestris L.), silver fir (Abies alba Mill.), and larch (Larix decidua Mill.).

No significant windthrows have occurred in the study region during recent decades, and annual amounts of wood damaged by wind have been relatively stable since 1972 . Bark beetle populations in the study region were small and in a (meta)stable stage at least during the period 1973-1992 (Slovak Forest Protection Service, internal data). A largescale outbreak began in 1993 and persists to the present (2012). The entire study area has been intensively managed, and control measures have been regularly applied. The amount of sanitary felling has varied in time with peaks in 1995-1996 and 2003-2005. Bark beetle populations were in an epidemic phase between these two peaks, when the amount of sanitary felling was several times higher than in 1973-1992, before the outbreak period. The infestation was mainly caused by $I$. typographus, Pityogenes chalcographus (L., 1761), Ips amitinus (Eichh. 1871) and Ips duplicatus (Sahlb., 1836) (Turčáni and Hlásny 2007). Field surveys confirmed that $I$. typographus accounted for up to $95 \%$ of the dead trees in the study region (Slovak Forest Protection Service, internal data).

\subsection{Data description}

The data used in this study were provided by forest owners/users as part of the annual reports that describe the amount of sanitary felling due to I. typographus for the period 1998-2004. The data are spatially referenced by forest compartments with a medium size of 4 ha. Throughout the study region, usually $90-100 \%$ of trees that are killed/infested in one season are already salvaged by the beginning of the next season. The dense transportation network in the study region and legal regulations, including a system of penalties for unsalvaged infested trees, indicate that most infested trees are felled.

Investigation of I. typographus dispersal was based on the absolute amounts of felled volume $\left(\mathrm{m}^{3}\right)$, while geostatistical analysis and regression modelling were based on the ratios of felled volume to the total spruce volume in a stand $\left(\mathrm{m}^{3} / \mathrm{m}^{3} \times 100\right)$ (Table 1$)$.

To facilitate geostatistical analyses and analysis of $I$. typographus dispersal, the original polygonal data (forest compartments) were transformed to point field, i.e. the amount of felling in a compartment was associated with a point located in the centre of the compartment. Given the size of the study region, no significant spatial information was lost by this transformation.

As used technique for regression modelling (Artificial Neural Networks) belongs to the data mining techniques, we collected all available variables, which can be supposed to affect stand susceptibility to I. typographus infestation 
Table 1 Statistics of amounts of sanitary felling due to Ips typographus infestation during the period 1998-2004 in the study region in the Western Beskids Mts

\begin{tabular}{|c|c|c|c|c|c|c|c|c|}
\hline Year & $N$ & Mean & Median & Minimum & Maximum & $25 \%$ quartile & $75 \%$ quartile & Sum \\
\hline 1998 & 398 & $55.1 / 2.8$ & $27.1 / 1.6$ & $0.3 / 0.01$ & $810.1 / 74$ & $4.1 / 0.4$ & $64.2 / 3.9$ & 22,056 \\
\hline 1999 & 1,118 & $59.3 / 2.9$ & $21.1 / 1.7$ & $0.6 / 0.01$ & $2,011.2 / 100$ & $2.3 / 0.4$ & $141.4 / 3.9$ & 66,170 \\
\hline 2000 & 775 & $40.7 / 2.6$ & $11.4 / 1.4$ & $0.2 / 0.01$ & 499.6/98 & $3.6 / 0.3$ & $45.5 / 3.2$ & 31,006 \\
\hline 2001 & 757 & 29.2/1.9 & $5.1 / 1.2$ & $0.8 / 0.01$ & $691.4 / 100$ & $2.4 / 0.2$ & $31.9 / 2.6$ & 22,159 \\
\hline 2002 & 658 & $29.6 / 1.8$ & $7.2 / 1.2$ & $0.4 / 0.01$ & $629.3 / 100$ & $2.2 / 0.3$ & $36.8 / 2.1$ & 19,478 \\
\hline 2003 & 1,012 & $50.3 / 2.4$ & 21.6/1.4 & $0.4 / 0.01$ & $600.1 / 100$ & $6.1 / 0.4$ & $63.4 / 3.8$ & 50,970 \\
\hline 2004 & 1,782 & $120.5 / 5.3$ & $50.1 / 2.9$ & $0.3 / 0.01$ & $1,782.2 / 100$ & $19.7 / 0.9$ & $131.5 / 5.2$ & 138,013 \\
\hline
\end{tabular}

$N$ number of forest compartments with reported sanitary felling; sum total felled volume; absolute amount of felling $\left(\mathrm{m}^{3}\right) /$ per cent of felled volume out of total volume of spruce in a stand $\left(\mathrm{m}^{3} / \mathrm{m}^{3} \times 100\right)$

without designating prior hypothesis on the effect of these variables. Mean spruce age in a stand, spruce proportion, stand vertical structure, stand density, mean stand DBH, spruce volume $\left(\mathrm{m}^{3} \mathrm{ha}^{-1}\right)$ and proportion of broadleaved were obtained from forest management plans (National Forest Centre, Slovakia, internal data). Average slope, aspect, elevation and potential solar irradiation of compartments were inferred from an elevation model with spatial resolution of $10 \mathrm{~m}$. Stand radiation and water regime were inferred indirectly from the composition of the herb layer at a stand (Forest Typology Maps, National Forest Centre, Slovakia, internal data). Climate characteristics were not used because few climatic stations are located in the study region and its surrounding and because elevation adequately represents the regional temperature pattern.

\subsection{Analysis of Ips typographus dispersal}

We investigated I. typographus dispersal based on the geographical occurrence of new infestations relative to previous ones (Byers 2000). We designated a series of concentric rings around all forest compartments with reported felling in year $y-1$. Each ring was $150 \mathrm{~m}$ wide, and the outer edge of the largest ring was $1350 \mathrm{~m}$ from the position of felling. This is the approximate distance of the inter-annual dispersal of I. typographus (e.g. Weslien and Lindelöw 2006), although the majority of beetles disperse $<500 \mathrm{~m}$ (Botterweg 1982; Wichmann and Ravn 2001).

The felled volume in year $y$ was determined for all rings (distance categories) constructed around the compartments with felling in year $y-1$. Next, the percentage of felled volume in each distance category relative to the total felled volume within the study region in each year was calculated; this value is referred to as the sectional percentage of felled volume. The total felled volume within a specified distance category, including all lesser-distance categories, is referred to as the cumulative percentage of felled volume.
The sectional percentages and cumulative percentages were plotted as a function of the distance for each of the following periods: 1998/1999, 1999/2000, 2000/2001, $2001 / 2002,2002 / 2003$ and 2003/2004. The resulting plots were investigated visually and interpreted in relation to outbreak development.

\subsection{Spatial dependence analysis and kriging}

Variogram modelling techniques are frequently used for the analysis of spatial dependence, which is typical of many biological systems and which can be assumed to be present in I. typographus distribution. Variogram parameters such as range, nugget effect and sill have been described many times in the literature. The data analysed in this study exhibit so-called anisotropical behaviour, i.e. the variogram parameters depend not only on the separation distance but also on the direction. This kind of pattern can be described by the socalled anisotropy ratio, i.e. the ratio of variogram ranges in directions of highest and lowest variability. Two forms of anisotropy were present in the analysed data: geometrical anisotropy (which occurs when variogram ranges in direction of lowest and highest variability are different while variogram sills remain constant) and zonal anisotropy (which occurs when both variogram ranges and sills are different in various directions).

Kriging represents an interpolation algorithm that enables one to predict values at locations lacking data on the basis of available sample data (sanitary felling data in this study). In this way, maps describing the spatial distribution of the investigated phenomenon can be produced. Because the underlying data in the current study meet the assumption of stationarity and because univariate prediction is intended, ordinary kriging will be considered herein.

ISATIS v.6 (Geovariances and Ecole des Mines de Paris 2002) was used for all geostatistical analyses. 


\subsection{Infestation sensitivity to stand and site conditions}

We used regression modelling to evaluate the effect of stand and site conditions on forest damage caused by $I$. typographus and to identify the factors that might cause possible anisotropies or other spatial patterns of infestation. The sanitary felling data (the percentage of felled volume relative to the total spruce volume in a stand, as described earlier) were used as the dependent variable, while selected stand and site characteristics were used as independent variables.

Neural network-based regression modelling was used for the analysis, following the workflow described by Hlásny et al. (2011). Regression models were designated independently for each year of the investigated period (1998-2004). Sensitivity analysis was used to indicate the relative importance of a given explanatory variable relative to the amount of felling. The sensitivity analysis used in this study iteratively "discards" an input variable and assesses the network error. The measure of sensitivity is the ratio of the error produced by a neural network with a missing variable relative to the original error yield with the full set of input variables. The more sensitive the network is to a particular input, the greater the deterioration expected, and therefore, the greater this ratio will be. Statistical analyses were run in Statistica Neural Networks v.10 (StatSoft Inc., 2004).

\section{Results}

\subsection{Ips typographus dispersal}

Analysis of I. typographus dispersal during 1998-2004 suggests that 1998/1999 was characterised by a high rate of dispersal and that more than $72 \%$ of the infestation (percentage of infested volume out of all infested volume in the study region in a given year) in 1999 occurred more than $1,000 \mathrm{~m}$ from the previous year's (1998) infestations (Fig. 1). In subsequent years, long-distance dispersal decreased remarkably. In $2000,61 \%$ of the infestation tended to be within $1,000 \mathrm{~m}$ of the infestation in 1999. The following years showed an even greater decrease in long-distance dispersal in that more than $87 \%$ of new infestations occurred within $1,000 \mathrm{~m}$ of the previous year's infestation spots.

We describe the dispersal also in terms of the percentage of felled volume that was within the closest and beyond the utmost ring. Following 1998/1999, the percentage within $150 \mathrm{~m}$ increased from $8.6 \%$ in $1999 / 1998$, to $29.3 \%$ in $2000 / 1999$ and to $50.6 \%$ in $2001 / 2000$. In the following years, this value remained high: $54.4 \%$ in $2002 / 2001$, $37.5 \%$ in $2003 / 2002$ and $60.7 \%$ in $2004 / 2003$. In contrast, the percentage of felled volume that was further than $1350 \mathrm{~m}$ decreased sharply from $63 \%$ in $1998 / 1999$ to
$29 \%$ in 1999/2000, and it remained constant during the rest of the period at approximately $6 \%$.

Variation of dispersal in relation to outbreak development as indicated by the amount of infested and felled wood (Fig. 2) suggests that beetles dispersed over long distances mainly in the transitional period between the two outbreak peaks; dispersal was greatest in 1999. In contrast, dispersal was lowest at the beginning and during the culmination of the second peak (2001-2004).

\subsection{Spatial patterns of infestation}

Investigation of the degree and orientation of spatial dependence of infestation suggested the presence of large-scale pattern that developed over time. The variographic analysis indicated that the direction of maximum continuity of infestation was $51^{\circ}$ (clockwise) in 2000 and that this angle slightly deviated from the angles observed in 2002-2004 (Fig. 3a). No anisotropical pattern was evident in 2001 (Fig. 3b). The most distinctive pattern was the geometrical anisotropy in 2002, 2003 and 2004 (Fig. 3c-e). The longer axis of anisotropical ellipse (indicating direction of highest continuity) passed during this period at an azimuth of about $30^{\circ}$. The longer ranges of spatial dependence reached 18, 28 and $24 \mathrm{~km}$, respectively. The anisotropy ratio increased over time and was 2.00 in 2002, 2.15 in 2003 and 3.40 in 2004. The position of the average anisotropical ellipse, which was calculated using variogram ranges and directions during 2002-2004, is presented in Fig. 4f.

At distances from 2 to $5 / \mathrm{km}$ (depending on year), empirical variograms are not separated, which suggests isotropy at smaller scales (stand or patch scale).

Ordinary kriging-based maps indicated that the spatial pattern of infestation was patchy, concentrated on several foci in 2000 (Fig. 4a). The pattern was the same in 2001-2002, when the highest intensity of infestation was in the south-central region (Fig. 4b, c). Between 2002 and 2003, the infested volume doubled, and the spatial distribution changed to continuous areas of intense infestation with strong spatial anisotropy (Fig. 4d). In 2004, the volume of infested trees tripled relative to 2003, which again resulted in a visible anisotropical structure. The outbreak reached a maximum, and the entire central part of the study area was heavily infested (Fig. 4e).

3.3 Ips typographus infestation in relation to stand and site parameters

Pearson's correlation coefficients $(R)$ between reported values and neural network-predicted values of sanitary felling $\left(\mathrm{m}^{3} / \mathrm{m}^{3} \times 100\right)$ suggest that the designated models have relatively low performance (Table 2). Unequal magnitude of $R$ between training, testing and validation sets also indicate poor performance of the models. Values of $R$ were 
$2004 / 2003$
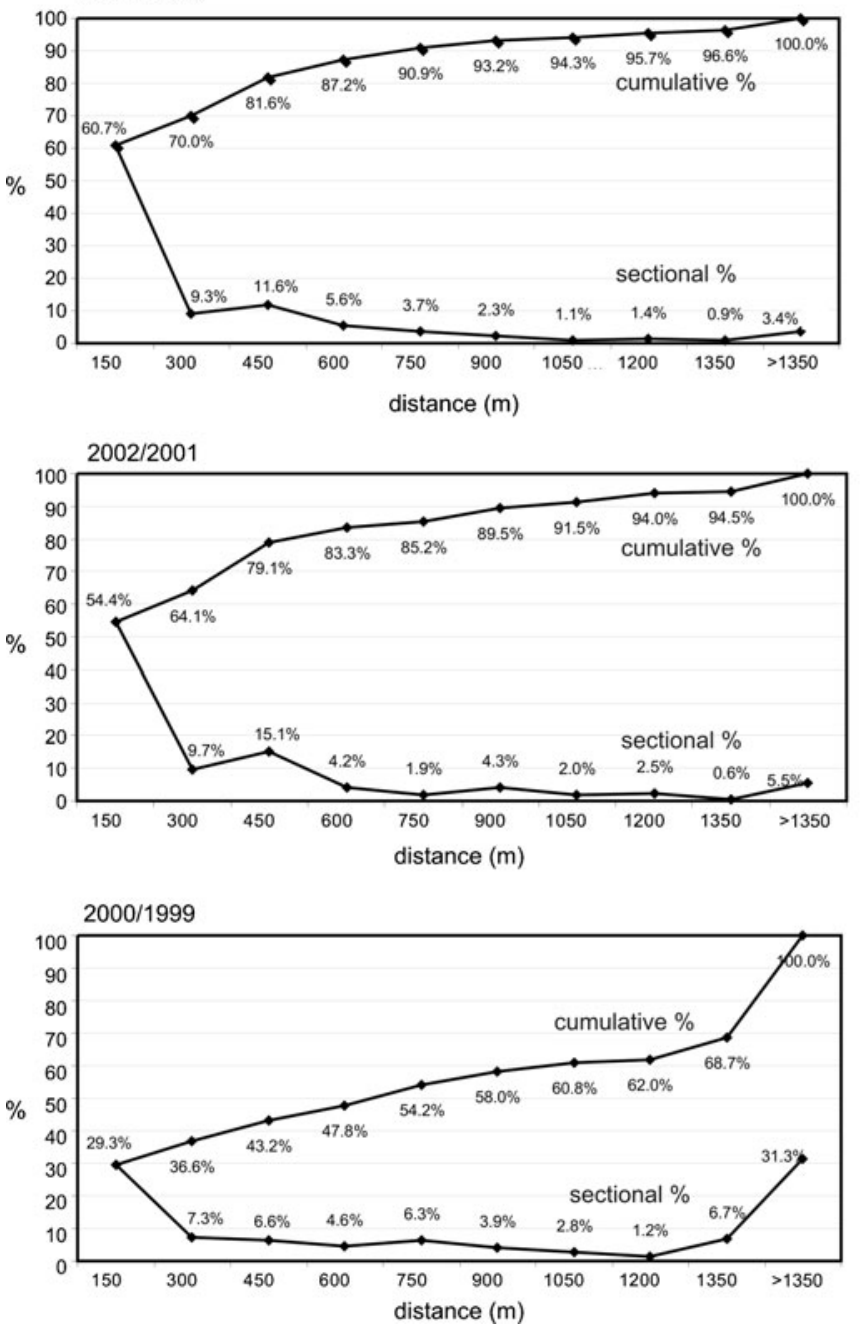

Fig. 1 Dispersal of Ips typographus as indicated by amount of felled trees in forest compartments in year $y$ relative to amount of trees felled in forest compartments in year $y-1$. Such calculation was performed
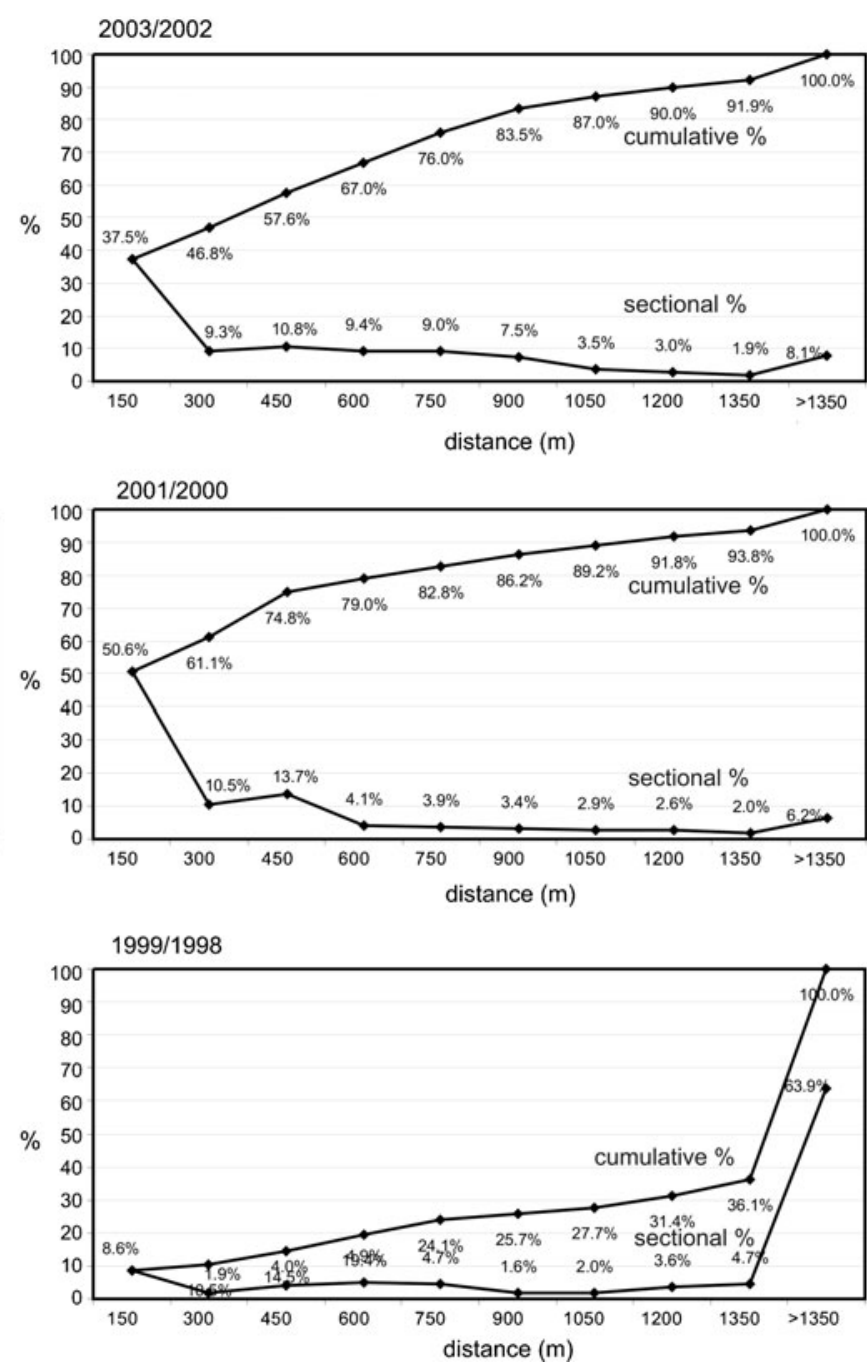

within nine distance categories with width of $150 \mathrm{~m}$ surrounding the compartments with felling in year $y$
Fig. 2 Development of $I$. typographus outbreak (as indicated by volume of felled infested trees and as represented by the bars) during the outbreak period of 1991-2005 in relation to Ips typographus dispersal (as indicated by the percentage of felled trees in year $y$ within $1,350 \mathrm{~m}$ from the centre of compartments with reported felling in year $y-1$ relative to the total amount of felling in the region) during the period 1999-2004

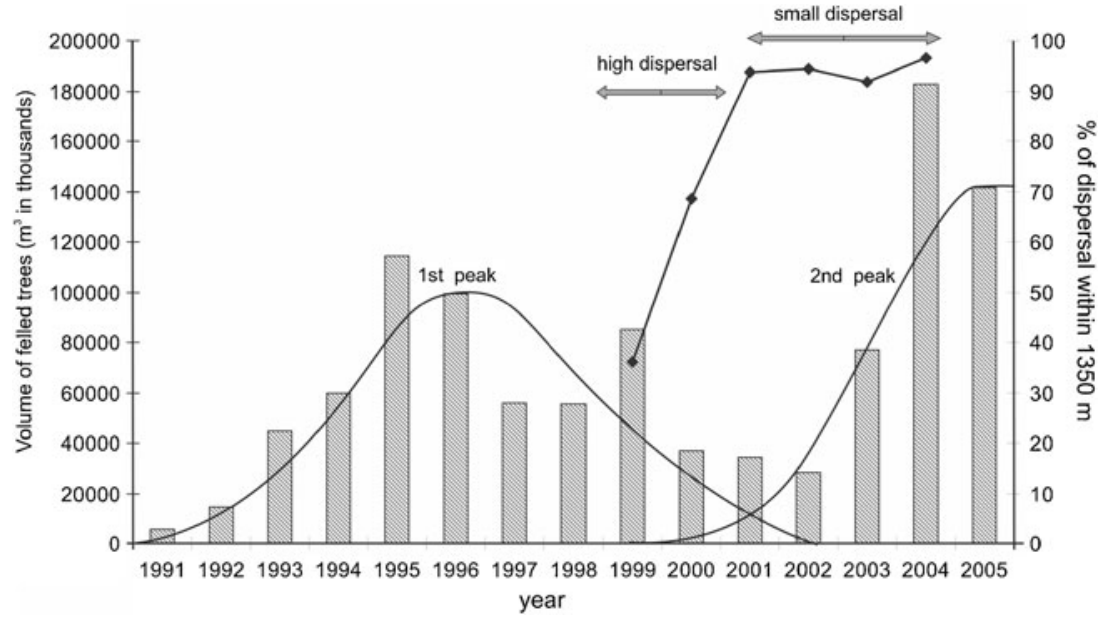



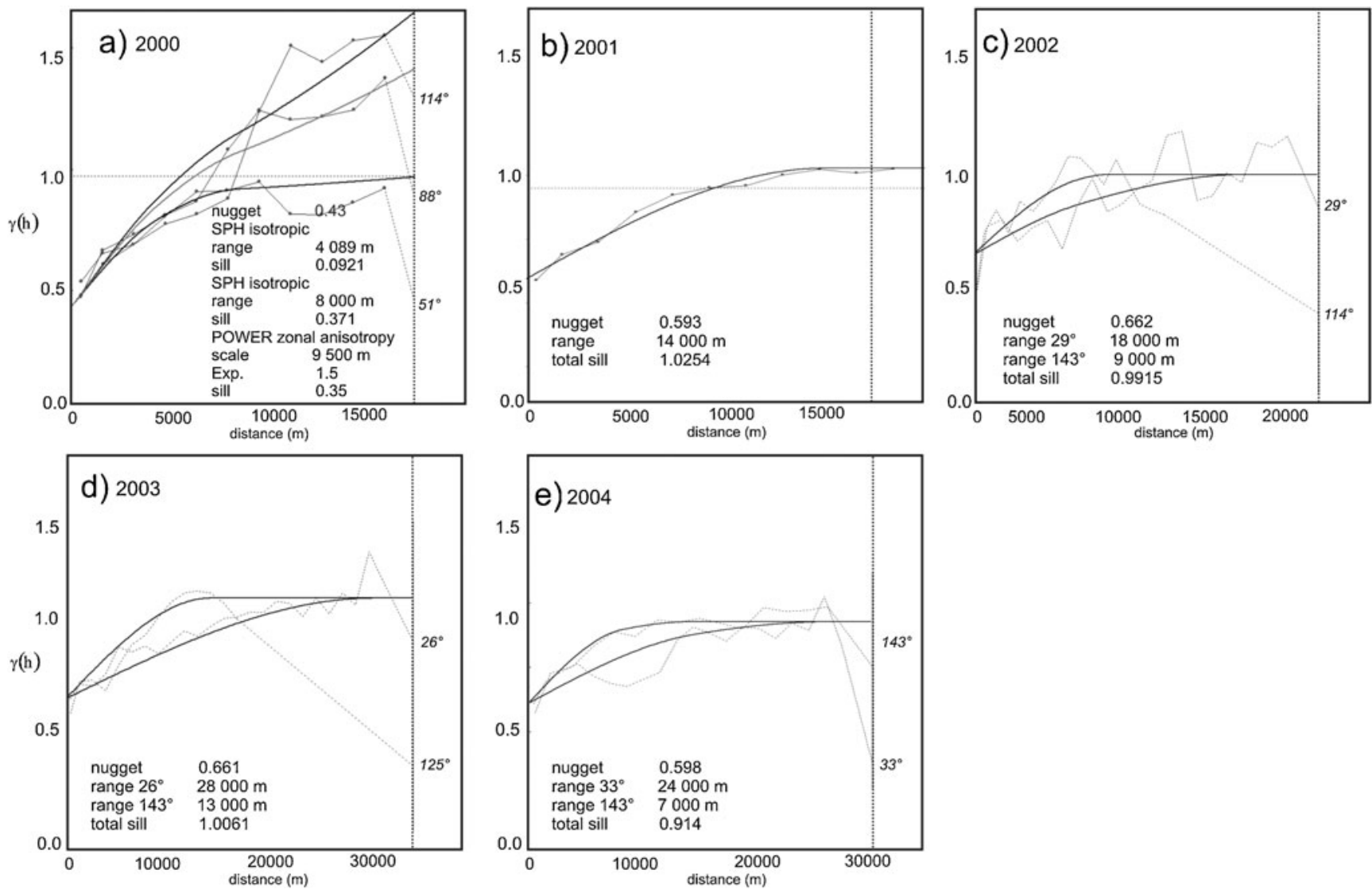

Fig. 3 The variograms of the amounts of sanitary felling (felled infested volume relative to total spruce volume in a stand) and related parameters in the period 2000-2004. Horizontal axis describes the distance $(h)$ that separates pairs of observation used to calculate the variogram value $(\gamma)$. Vertical axis describes the

spatial variability of the amounts of volume infested by Ips typographus separated by distance $(h)$. Thin lines denote empirical variogram values, while thick line denotes fitted empirical variogram. Angles in the right sides $\left(^{\circ}\right)$ denote direction in which the variograms have been calculated

higher for years 1998-2000 than for later years, indicating that the independent variables explained more of the variation in infestation in 1998-2000 than in 2001-2004.

The sensitivity analysis (Table 3 ) indicated that most of the explanatory variables in all years had sensitivity scores near 1.000 , which suggests that the variables had no effect on the infestation. In most years, sensitivity scores were higher for stand age and spruce proportion in a stand than for the other explanatory variables.

\section{Discussion and conclusions}

In this study, we have attempted to describe the spatial and temporal patterns of damage caused by I. typographus to declining spruce forests in the Western Beskids Mts., which are among the most damaged forests in Europe. This region differs in some respects from other environments where bark beetles have been studied mainly because of the presence of spruce monocultures that were artificially planted for several generations for commercial purposes. In addition, several periods of forest decline have occurred in this region in recent decades (Hlásny and Sitková 2010), which indicates that the ecological limits for spruce persistence may have been exceeded.

\subsection{Methodological comments and limitations}

The suitability of sanitary felling data for the presented analyses can be questioned, and such data have been used only infrequently for the investigation of forest disturbances (e.g. Økland and Berryman 2004) or hazard rating (e.g. Netherer and NoppMayr 2005). Presented results indicate, however, that sanitary felling data can be valuable because of their stand-based localisation, quantitative scale and applicability for temporal analysis. Given the legislation and control system in the region of the current research, including a system of penalties for unsalvaged infested trees, we assume that most of the infested trees were felled and recorded. A complete data set is, however, not a prerequisite for assessing presented dispersal and damage patterns. The described geostatistical methods enable the proper assessment of such patterns using sample data. 


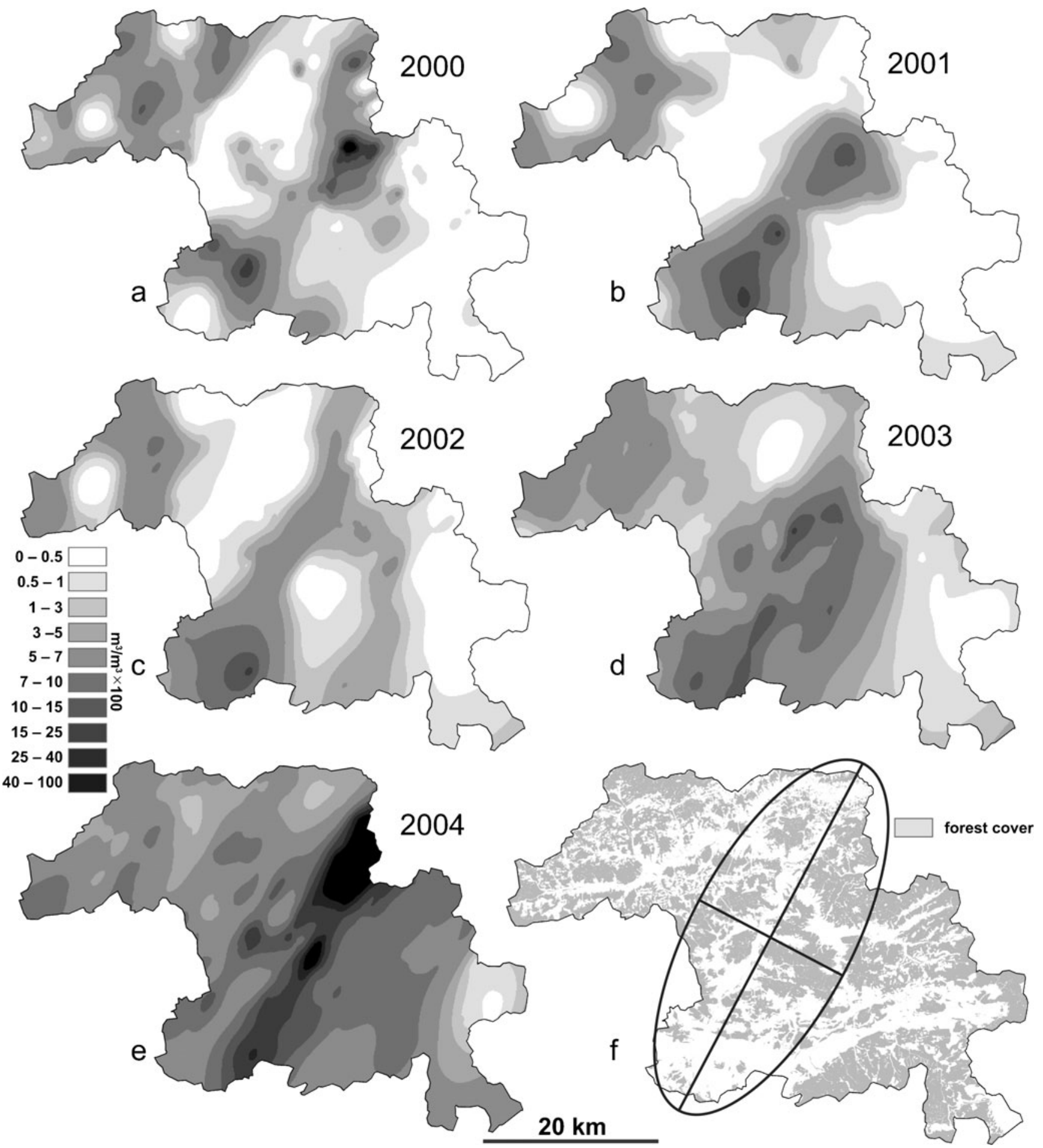

Fig. 4 Infestation of forest stands in 2000-2004 in the study region as indicated by ordinary kriging. $f$ shows the position of the average anisotropical ellipse for years 2002-2004. The ratio and angle of the anisotropical ellipse were preserved but not the size

The analysis of I. typographus dispersal in relation to population size assumes that the volume of infested trees can be used as proxy for population size; such estimates are often based on pheromone trap data (Kausrud et al. 2011). Although no experiment has demonstrated a relationship between infested wood volume and I. typographus population size in the study region, Lindelöw and Schroeder (2001), Faccoli and Stergulc (2004) suggest that there is a tight correlation between the number of trapped beetles and infested 
Table 2 Pearson's correlation coefficient between neural networkpredicted and observed percentage of sanitary felling due to Ips typographus infestation relative to total volume of spruce in a stand calculated for training, testing and validation data sets

\begin{tabular}{llll}
\hline Year & Training & Testing & Validation \\
\hline 1998 & 0.55 & 0.40 & 0.52 \\
1999 & 0.61 & 0.44 & 0.49 \\
2000 & 0.42 & 0.27 & 0.51 \\
2001 & 0.38 & 0.37 & 0.25 \\
2002 & 0.44 & 0.48 & 0.21 \\
2003 & 0.27 & 0.38 & 0.30 \\
2004 & 0.26 & 0.45 & 0.28 \\
\hline
\end{tabular}

wood volume or number of killed trees. We used this assumption in the present analysis.

Removal of infested trees can substantially affect the size and distribution of bark beetle populations (Jönsson et al. 2012; Wichmann and Ravn 2001), and it follows that the observed patterns should be thought of as generated under a management system involving the permanent removal of infested trees. Because sanitary felling relates to stand or sub-stand scale, such interventions could mainly affect infestation response to stand and site characteristics as well as contribute to small-scale variability of infestation in the presented variograms (nugget effect). In contrast, if sanitary measures had significantly controlled population growth, we would have expected a fragmented pattern of infestation at the regional scale; this was not the case and the presented variograms showed high degree of spatial continuity at larger distances.
4.2 Main findings and recommendations

\subsubsection{Dispersal patterns}

Successful colonisation of host trees by beetles is a result of complex interactions between the density of attacking beetles and host physiology and the host's subsequent ability to defend (Nelson and Lewis, 2008). We argue that the observed changes in I. typographus dispersal were related mainly to the changes in its population density, which was approximated based on the volume of infested trees. The presence of homogenous stands growing in suboptimal conditions and results of regression analysis imply little difference in stand's resistance to infestation. The observed dispersal patterns suggest that I. typographus population size exceeded the threshold for successful attack of most trees in the region after the first 2 years of the investigation. Subsequent attacks tended to be less selective, and search distance decreased remarkably. In addition, control of stand and site condition over the infestation was weaker in this period as compared with the first 2 years of the investigations as was indicated by correlation coefficients between observed and predicted values. The resulting concentrated and intensive infestation along with dead tree removal further amplified the vulnerability of the spruce forest by generating new forest edges and by opening the canopy, which increases stand susceptibility to bark beetle attacks (Lobinger and Skatulla 1996); this can be supposed to further reduce the long-distance dispersal.

We infer that the long-distance dispersal from the initial infestation areas was triggered by resource depletion after the first outbreak peak (1995-1999) and that this long-

Table 3 Average sensitivity scores of explanatory variables relative to the observed percentage of sanitary felling due to Ips typographus infestation (relative to total spruce volume in a stand) during 1998-2004

\begin{tabular}{|c|c|c|c|c|c|c|c|c|}
\hline & Year & & & & & & & \\
\hline Explanatory variables & Source & 1998 & 1999 & 2000 & 2001 & 2002 & 2003 & 2004 \\
\hline Mean age of spruce & Forest management plans & 2.102 & 1.228 & 1.203 & 1.198 & 1.189 & 1.123 & 1.910 \\
\hline Spruce proportion & & 1.952 & 1.895 & 1.918 & 1.165 & 2.001 & 2.101 & 1.107 \\
\hline No. of vertical layers & & 1.187 & 1.067 & 0.999 & 1.110 & 1.000 & 1.150 & 1.201 \\
\hline Mean stands density & & 1.036 & 1.150 & 0.999 & 1.110 & 1.164 & 1.205 & 1.110 \\
\hline Mean stand DBH & & 1.052 & 1.010 & 0.997 & 1.033 & 1.110 & 1.100 & 1.091 \\
\hline Spruce volume & & 1.179 & 1.455 & 1.033 & 1.110 & 1.179 & 1.411 & 1.050 \\
\hline Proportion of broadleaved & & 1.178 & 1.219 & 1.034 & 1.218 & 1.174 & 1.530 & 1.019 \\
\hline Elevation & Digital elevation model & 1.163 & 1.000 & 1.000 & 1.003 & 1.188 & 1.010 & 1.114 \\
\hline Terrain slope & & 0.999 & 1.160 & 1.039 & 1.067 & 1.150 & 1.001 & 1.110 \\
\hline Terrain aspect & & 1.051 & 1.109 & 1.102 & 1.053 & 1.010 & 1.080 & 1.000 \\
\hline Potential solar irradiation & & 1.111 & 1.000 & 1.169 & 1.000 & 1.003 & 1.032 & 1.110 \\
\hline Stand radiation regime & Forest typology maps & 1.003 & 1.000 & 1.051 & 1.129 & 1.174 & 1.211 & 0.999 \\
\hline Stand water regime & & 1.155 & 1.036 & 0.988 & 1.133 & 1.010 & 1.110 & 0.996 \\
\hline
\end{tabular}

The largest sensitivity scores in each year are in italics. 
distance dispersal was supported by the availability of a large number of trees distributed over the region that were susceptible to attack. Our observations agree with Jakuš et al. (2003), who found that long-distance dispersal occurred mainly during the first stage of outbreak in the High Tatra Mts. (Central Europe), when beetles migrated over long distances to locate new food sources. The subsequent short-distance dispersal at the beginning and the culmination phases of the second peak (2001-2004) in the current study could be associated with the increased abundance of $I$. typographus and the consequent increase in beetle's ability to attack more resistant trees (Kausrud et al. 2011; Schroeder and Lindelöw 2002). Similarly, Botterweg (1982) and Wichmann and Ravn (2001) found that under epidemic conditions, the likelihood of infestations around old infestations decreases sharply beyond $100 \mathrm{~m}$; between $500 \mathrm{~m}$ and $1 \mathrm{~km}$ any local relationship between old infestations and subsequent tree mortality is absent. Observed nonlinear response of dispersal to outbreak development (Fig. 2) corresponds with Botterweg (1982), who suggested that there seems to be no linear link between density and long-range dispersal of I. typographus. We argue, on the basis of the presented findings, that the principle of $I$. typographus dispersal in relation to population density in the investigated spruce forests is approximately the same as has been reported from other environments.

\subsubsection{Spatial patterns of infestation}

Analysis of the empirical variograms presented in this study indicates isotropical spread at shorter distances and directional spread at larger distances. This means that at the level of stands, I. typographus spread isotropically, and there were, on average, no significant differences among stands in their resistance to infestation. At the regional scale, however, some large-scale processes resulted in greater spread in the northeast-southwest direction than in the perpendicular direction. The cause of this anisotropy is unknown.

As indicated by the presented maps, the area of infested stands rapidly expanded from a few initial infestation areas as beetles dispersed to reach new food resources. In addition, occupation of these stands was probably supported by growth of local populations. Although the trade-off between these two processes cannot be estimated (Byers 2000), the observed patterns of infestation indicate the dominance of large-scale spread from the initial spots. Such spread is likely to occur in monocultures because of lack of barriers (such as zones of non-host tree species or zones differentiated by spruce age or genetic structure) that prevent or slow I. typographus dispersal.

Although the spatial development of outbreaks is difficult to predict (Wermelinger 2004), based on this information, forest managers are advised to increase the intensity of forest protection measures in those stands in the path of more intensive spread. Although such information is region-specific, the presented use of geostatistical tools for the exploration of patterns of I. typographus-induced damage to forests should be broadly applicable.

\subsubsection{Effect of stand and site conditions}

Based on the results of the regression modelling and geostatistical analyses, we argue that I. typographus dispersal and subsequent infestation were little influenced by stand and site parameters. Among these parameters, stand age and spruce proportion in a stand were the most influential albeit weak variables. This follows that lower concentration of food resources may prevent pests from building up their populations (Jactel and Brockerhoff, 2007) and non-host trees may provide barriers to host location or colonisation; and that trees with bigger diameter are preferentially attacked (Göthlin et al. 2000). In fact, tree species composition and stand age are important predictors in bark beetle hazard rating models such as PAS (Netherer and Nopp-Mayr 2005).

On the one hand, these findings may not be useful for forest management because they only confirm generally recognised facts regarding I. typographus food preferences (Christiansen and Bakke 1988; Wermelinger 2004) and do not enable the identification of vulnerable stands. In addition, intensive removal of infested trees might hinder the interpretation of such response because canopy opening increases stand susceptibility (Lobinger and Skatulla, 1996), and this effect may mask the inherent effect of stand and site condition. This also suggests that sanitary felling data may have limited usefulness for the parameterisation of hazard rating models under high population densities. On the other hand, these findings indicate that the allocation of forest protection measures should be based on the observed principles of horizontal spread rather than on the rating of stand hazard, and that, under epidemic conditions, the perspective of forest management should shift from the stand to the regional scale.

\subsection{Final remarks}

The observations presented here, along with the unprecedented I. typographus outbreaks observed worldwide (Schelhaas et al. 2003), indicate the need for a radical and near-term decrease in the extent of secondary spruce forests. The approximate area covered by secondary conifer forests in Europe was estimated to be between 5.7 and 7.3 mill. hectares (Seidl et al. 2008). These forests should be converted to forests with tree species that are better suited to the sites with more diverse stand structure (Hlásny and Sitková 2010). Maintenance of stand diversity and introduction of broadleaved species should 
increase resistance to windthrow and bark beetle attack (Griess et al. 2012) and secure the sustainable provision of ecosystem functions, goods and services. Anticipated changes in climate will likely amplify the vulnerability of secondary spruce forests growing in suboptimal sites because of increased impact of biotic agents and adverse effect of drought, the factors which are expected to be more pronounced in Central Europe in the future (Lindner et al. 2010). The very large amounts of timber infested by I. typographus in Europe after the heat wave in 2003 (Rouault et al. 2006) demonstrates the unsustainability of such forests.

Acknowledgment The authors thank Dr. Bruce Jaffee for linguistic and editorial improvement.

Funding This research was supported by project of the Agency of the Slovak Ministry of Education ITMS 26220120069 (60\%), Slovak Research and Development Agency under contract APVV-0111-10 (30\%), National Agency for Agriculture Research of the Czech Republic within the frame of project QJ1220317 and project CIGA no. 20114312 of the Czech University of Life Sciences Prague (10\%).

\section{References}

Botterweg PF (1982) Dispersal and flight behaviour of the spruce bark beetle Ips typographus in relation to sex, size and fat content. $\mathrm{Z}$ Angew Entomol 94:466-489. doi:10.1111/j.14390418.1982.tb02594.x

Byers JA (2000) Effects of attraction radius and flight paths on catch of scolytid beetles dispersing outward through rings of pheromone traps. J Chem Ecol 25:985-1005. doi:10.1023/A:1020869422943

Christiansen E, Bakke A (1988) The spruce bark beetle of Eurasia. In: Berryman AA (ed) Dynamics of forest insect populations: patterns, causes, implications. Plenum, New York, pp 479-503

Dutilleul P, Nef L, Frigon D (2000) Assessment of site characteristics as predictors of the vulnerability of Norway spruce (Picea abies Karst.) stands to attack by Ips typographus L. (Col., Scolytidae). J Appl Entomol 124:1-5. doi:10.1046/j.1439-0418.2000.00440.x

Faccoli M, Stergulc F (2004) Ips typographus (L.) pheromone trapping in south Alps: spring catches determine damage thresholds. J Appl Entomol 128:307-311. doi:10.1111/j.14390418.2004.00848.307

Führer E (1990) Forest decline in Central Europe: additional aspects of its cause. For Ecol Manag 37:249-257. doi:10.1016/03781127(90)90094-R

Göthlin E, Schroeder LM, Lindelöw A (2000) Attacks by Ips typographus and Pityogenes chalcographus on windthrown spruces (Picea abies) during the two years following a storm felling. Scand J Forest Res 15:542-549. doi:10.1080/ 028275800750173492

Griess VC, Acevedo R, Härtl F, Staupendahl K, Knoke T (2012) Does mixing tree species enhance stand resistance against natural hazards? A case study for spruce. For Ecol Manag 267:284-296. doi:10.1016/j.foreco.2011.11.035

Grodzki W (2010) The decline of Norway spruce Picea abies (L.) Karst stands in Beskid Śląski and Żywiecki: Theoretical concept and reality. Beskydy 3:19-26

Hlásny T, Kř́stek Š, Holuša J, Trombik J, Urbaňcová N (2011) Snow disturbances in secondary Norway spruce forests in Central
Europe: regression modeling and its implications for forest management. For Ecol Manag 262:2151-2161. doi:10.1016/ j.foreco.2011.08.005

Hlásny T, Sitková Z (2010) Spruce forests decline in the Beskids. National Forest Centre, Forest Research Institute Zvolen, Czech University of Life Sciences Prague, Forestry and Game Management Research Institute Jíloviště-Strnady, Zvolen

Jactel H, Brockerhoff E (2007) Tree diversity reduces herbivory by forest insects. Ecol Lett 10:835-848. doi:10.1111/j.14610248.2007.01073.x, DOI:10.1111\%2Fj.1461-0248.2007.01073.x

Jakuš R, Grodzki W, Ježik M, Jachym M (2003) Definition of spatial patterns of bark beetle Ips typographus (L.) outbreak spreading in Tatra Mountains (Central Europe), using GIS. In: McManus M, Liebhold A (eds) Ecology, survey and management of forest insects. Proceedings of the conference. USDA Forest Service, Warren, pp 25-32

Jönsson AM, Harding S, Bärring L, Ravn HP (2007) Impact of climate change on the population dynamics of Ips typographus in southern Sweden. Agric For Meteorol 146:70-81. doi:10.1016/ j.agrformet.2007.05.006

Jönsson AM, Schroeder LM, Lagergren F, Anderbrant O, Smith B (2012) Guess the impact of Ips typographus - an ecosystem modelling approach for simulating spruce bark beetle outbreaks. Agric For Meteorol 166-167:188-200. doi:10.1016/ j.agrformet.2012.07.012

Kausrud K, Okland B, Skarpass O, Grégoire JC, Erbilgin N, Stenseth NC (2011) Population dynamics in changing environments: the case of an eruptive forest pest species. Biol Rev 87:34-51. doi:10.1111/j.1469-185.2011.00183

Klopcic M, Poljanec A, Gartner A, Boncina A (2009) Factors related to natural disturbances in mountain Norway spruce (Picea abies) forests in the Julian Alps. Ecoscience 16:48-57. doi:10.2980/161-3181, DOI:10.2980\%2F16-1-3181

Lindner M, Maroschek M, Netherer S, Kremer A, Barbati A, GarciaGonzalo J, Seidl R, Delzon S, Corona P, Kolström M, Lexer M, Marchetti M (2010) Climate change impacts, adaptive capacity, and vulnerability of European forest ecosystems. For Ecol Manag 259:698-709. doi:10.1016/j.foreco.2009.09.023

Lindelöw A, Schroeder M (2001) Spruce bark beetle, Ips typographus (L.), in Sweden: monitoring and risk assessment. J For Sci 47:40 42

Lobinger G, Skatulla U (1996) Untersuchungen zum Einfluss von Sonnenlicht auf das Schwärmverhalten von Borkenkaäfern. Anz Schad1 69:183-185. doi:10.1007/BF01908442, DOI: $10.1007 \% 2 \mathrm{FBF} 01908442$

Mulock P, Christiansen E (1986) The threshold of successful attack by Ips typographus on Picea abies: a field experiment. For Ecol Manag 14:125-132. doi:10.1016/0378-1127(86)90097-6, DOI:10.1016\%2f0378-1127(86)90097-6

Nelson W, Lewis M (2008) Connecting host physiology to host resistance in the conifer-bark beetle system. Theor Ecol 1:163-177. doi:10.1007/s12080-008-0017-1

Netherer S, Nopp-Mayr U (2005) Predisposition assessment systems (PAS) as supportive tools in forest management - rating of site and stand-related hazards of bark beetle infestation in the High Tatra Mountains as an example for system application and verification. For Ecol Manag 207:99-107. doi:10.1016/ j.foreco.2004.10.020

Økland B, Berryman A (2004) Resource dynamic plays a key role in regional fluctuations of the spruce bark beetles Ips typographus. Agric For Entomol 6:141-146. doi:10.1111/j.14619555.2004.00214.x, DOI:10.1111\%2Fj.1461-9555.2004.00214.x

Raffa KF, Aukema BH, Bentz BJ, Carroll AL, Hicke JA, Turner MG, Romme WH (2008) Cross-scale drivers of natural disturbances prone to anthropogenic amplification: dynamics of biome-wide 
bark beetle eruptions. BioScience 58:501-517. doi:10.1641/ B580607

Rouault G, Candau J-N, Lieutier F, Nageleisen L-M, Martin J-C, Warzée N (2006) Effects of drought and heat on forest insect populations in relation to the 2003 drought in Western Europe. Ann For Sci 63:613-624. doi:10.1051/forest:2006044

Schelhaas M-J, Nabuurs G-J, Schuck A (2003) Natural disturbances in the European forests in the 19th and 20th centuries. Glob Chang Biol 9:1620-1633. doi:10.1046/j.1365-2486.2003.00684.x

Schroeder LM, Lindelöw A (2002) Attacks on living spruce trees by bark beetle Ips typographus (Col. Scolytidae) following a storm felling: a comparison between stands with and without removal of wind-felled trees. Agric For Entomol 4:47-56. doi:10.1046/ j.1461-9563.2002.00122.x

Seidl R, Rammer W, Lasch P, Badeck FW, Lexer MJ (2008) Does conversion of even-aged, secondary coniferous forests affect carbon sequestration? A simulation study under changing environmental conditions. Silva Fenn 42:369-386

Siefermann-Harms D, Boxer-Baldoma C, Wilpert K, Heuman H (2004) The rapid yellowing of spruce at a mountain site in the central Black forest (Germany). Combined effects of $\mathrm{Mg}$ deficiency and ozone on biochemical, physiological and structural properties of the chloroplasts. J Plant Physiol 161:423-437. doi:10.1078/0176-1617-01095

Tomiczek CH (1995) Nutrient deficiency of spruce needles caused by root and butt rots - a factor in forest decline. J Arboric 21:113-117

Turčáni M, Hlásny T (2007) Spatial distribution of four spruce bark beetles in north-western Slovakia. J For Sci 53:45-53

Uniyal SK, Uniyal A (2009) Climate change and large-scale degradation of spruce: common pattern across the globe. Climate Res 38:261-263. doi:10.3354/cr00792, DOI:10.3354\%2Fcr00792

Wermelinger B (2004) Ecology and management of the spruce bark beetle Ips typographus - a review of recent research. For Ecol Manag 202:67-82. doi:10.1016/j.foreco.2004.07.018

Weslien J, Lindelöw A (2006) Trapping a local population of spruce bark beetles Ips typographus (L.): population size and origin of trapped beetles. Ecography 12:511-514. doi:10.1111/j.16000587.1989.tb00929.x

Wichmann L, Ravn HP (2001) The spread of Ips typographus (L.) (Coleoptera, Scolytidae) attacks following heavy windthrow in Denmark analysed using GIS. For Ecol Manag 148:31-39. doi:10.1016/S0378-1127(00)00477-1 